The Importance of Emotional Intelligence in the Management of a Playwork Setting James Boddey \& Angela Hodgkins

boddeyjames@gmail.com

a.hodgkins@worcs.ac.uk.

Our philosophy, as a manager and former manager of playwork settings, is that the most important resource in the organisation is the people involved within it. James has managed a playwork setting for four years and Angela has managed a range of establishments during her twenty year career._At the beginning of our careers, we both believed that acquiring experience and knowledge of children and associated theory was the key to effective training and development. However as our careers developed, our opinions changed. Goleman's (1996) work on Emotional Intelligence has had a significant impact on how James leads and supports his playwork team, and in this article we reflect on how an appreciation of emotional intelligence may produce more effective playwork practitioners.

The Oxford Dictionary (2014) defines Emotional Intelligence (EQ) as, "The capacity to be aware of, control, and express one's emotions and to handle interpersonal relationships judiciously and empathically". This involves critically reflecting on our thoughts, actions, feelings and emotions as well as considering how we interact, empathise and communicate with others. Salovey and Mayer (1990_p189) define emotional intelligence as, "the subset of social intelligence that involves the ability to monitor one's own and others' feelings and emotions, to discriminate among them and to use this information to guide one's thinking and actions".

It is our belief that the most effective way to support members of staff is to demonstrate and promote emotional intelligence. As professionals, we sometimes focus so much on knowledge and understanding of the theory of playwork that we lose focus of the most important aspect that needs to be developed and trained, which in our opinion, is ourselves. However as Goleman (1996:4) suggests, "A view of human nature that ignores the power of emotions is short-sighted. As we all know from experience, when it comes to shaping our decisions and our actions, feeling counts every bit as much - and often more - than thought". One-of the key implications of Goleman's book is that traditional measures of 10 , academic grades and learned skills may have limited relevance to the job role of a play ork practitioner. Formal qualifications are being increasingly valued in the playwork field and , the National Occupational Standards for Playwork are very much a "how to" guide to the practicalities of the role, providing a theoretical framework to learn and follow. Developing our understanding of the subject of playwork is an ongoing and meaningful activity, and we believe that knowledge of theory is important. The National-Oecupational Standards are very much a 
"how to" guide to the practicalities of the role, a theoretical framework to learn and follow.-However, if we just develop our knowledge and understanding of the subject there is a danger that we become excellent and well-read playwork robots. Emotions, relationships, communication and empathy are all important aspects of the playwork provision and also need to be trained, developed and supported. One of the key implications of Goleman's book is that traditional measures of IQ, academic grades and learned skills may have limited relevance to the job role of a playwork practitioner.

\section{Categories of emotional intelligence}

According to Ackers \& Porter (2003: p65-69), there are five major categories of emotional intelligence, which we believe are essential in the management of a playwork setting. These are self-awareness, self-regulation, motivation, empathy and social skills.

\section{Self-Awareness}

The ability to recognize an emotion as it "happens" is the key to EQ. Developing self-awareness requires tuning in to your true feelings (Ackers \& Porter 2003). Self-awareness is also linked to self confidence and sureness about your self-worth and capabilities. In playwork provision, we need to create an environment where young people can build their confidence and develop good self worth by allowing them to be creative, encourage them to try things out and discover their own strengths and areas to develop. Staff can be great role models of these qualities, and therefore managers should support staff in becoming more self-aware. Effective playwork practitioners need to be self aware, self critical and be able to reflect on their own practice. Brookfield (2005: p67) advocated creating a balance between credibility and authenticity $y_{\overline{1}}$ suggesting that educators should practice what they preach and be sure not to espouse one way of working and then behave in a different way in their training of others.

We believe that a good sense of self-worth in ourselves will encourage those around us to flourish and develop in their own unique ways. Managers who are emotionally intelligent and who share their own thoughts and feelings may encourage others to do the same. Being aware of our own strengths, areas to develop, biases and experiences may lead to improvement and development. Through supervision meetings with individual staff members and informal comments recognising and celebrating their successes, managers can help their teams to develop self awareness. It is also important to allow individuals the time and space to critically reflect on their actions, skills and abilities.

\section{Self-Regulation}


As human beings, we may have little control over when we experience emotions ${ }_{L}$ but we can control how we handle them. An unavoidable feature of any playwork provision will involve challenges, complaints or change, which can suddenly develop without prior warning. In these instances we need to be able to react in the most positive and professional way possible. People in our playwork settings need self-control in order to control their emotions and deal with them appropriately. Times of challenge and change can be fantastic learning opportunities and a way for the young people in our care to see that we are human beings, with emotions that we need to regulate and handle appropriately.

\section{Motivation}

Motivating staff is one of a manager's key roles; "creating a share sense of achievement and belonging...the leader must show trust in the team while treating each member fairly as an individual" (Jones \& Pound, 2003: p34). People who are inspired or motivated are often described as "in the zone" or, as Sir Ken Robinson (2013: p5) describes it, "in their element". For people who are in their element, who are doing what they love, says Robinson, "an hour feels like five minutes...it gives you energy". As a leader of a playwork setting, we want our teams to be happy, motivated, inspired and flourishing as individuals. We believe that motivation and inspiration are essential attributes that we look for in a member of staff. To be able to motivate yourself to achieve requires clear goals and a positive attitude. We strive to promote an environment where people are encouraged to constantly reflect and improve. Motivation also requires persistence and a willingness to continue even when obstacles and setbacks occur. Good and trusting relationships with staff will foster resilience in the children and young people in our care (Newman, 2004).

\section{Empathy}

Being empathetic is a skill that is essential when working with others. The ability to recognise how people feel is important in all aspects of personal and professional life (Ackers \& Porter 2003), but we feel that it is particularly important when working with children and young people. Seeing things from others' perspectives enables us to work together more effectively. When we truly empathise with others, we can understand their actions and reactions. As playwork practitioners, we need to be adaptable and recognise that each individual will have their own needs, abilities and skills. The best practitioners can empathise with children, families and other members of staff. They can "put themselves in the shoes" of others and begin to see things from different perspective. Practitioners need to be able to make strong, equal relationships with each young person and their family. At staff meetings and one-to-one supervision meetings, James provides opportunity for each staff member to develop their empathy skills by encouraging staff to see things from different peoples' perspectives. 


\section{Social Skills}

The playwork environment is a very sociable place and therefore -good communication skills and the ability to listen are key skills for a successful playwork practitioner. In the context of playwork however, listening is not enough; we also need to be in tune and truly actively listening to others. Active listening is "a state of mind that involves paying full and careful attention to the other person, avoiding premature judgement, reflecting and understanding, clarifying information, summarising and sharing" (Hoppe, 2006: p6). This involves using our knowledge and understanding as well as our emotional intelligence when listening to someone in a meaningful way.

\section{Conclusion}

Understanding the theory of emotional intelligence leads us to examine how it underpins our thoughts and actions within the playwork field. Emotional ilntelligence comprises a flexible set of skills that can be acquired and improved with practice. The skills described in this article can play a vital role in the day to day life of a playwork setting, the relationships we make and how we communicate with each other. If we are emotionally intelligent then we can truly listen to someone, empathise with them, understand them and build a relationship with them.

We believe that in order to develop our emotional intelligence, we need to move away from being "expert holders of knowledge" and instead become more fluid, open and reflective in order to become experts on ourselves. It is important to embrace flexibility and change and to follow McNiff's (2006) advice, when she says, "we can afford to hold our knowledge lightly because we are confident in who we are". Therefore, we suggest that it is important to hold both professional and personal knowledge lightly, in order to adapt and adjust our position as we develop our practice. Knowledge of the Playwork Principles (PPSG 2005), theories and ideas are of course important, but in order to build caring relationships with young people, families and other professionals, we need to be emotionally intelligent practitioners, which means being empathic and having good self-confidence and self-awareness. As managers in playwork settings, we should consider the role of emotional intelligence could play in the training and development of our playwork practitioners.

James Boddey is the manager of Busy Bodies Childcare Centre in Ludlow, Shropshire. 


\section{Reference List}

Akers, M.D. and Porter, G.L., (2003), Your EQ skills: Got what it takes?, Journal of Accountancy, Vol 195, Iss 3, pp 65-69, American Institute of Certified Public Accountants, New York

Brookfield, Stephen (2005) The Power of Critical Theory for Adult Learning and Teaching, Berkshire: Oxford University Press

Goleman, Daniel (1996) Emotional Intelligence, London: Bloomsbury

Hoppe, Michael (2011) Active listening : improve your ability to listen and lead, North Carolina, Centre for Creative Leadership

Jones, Caroline \& Pound, Linda (2008) Leadership and Management in the Early Years, Oxford, Open University Press

McNiff, J. and Whitehead, J. (2006) All You Need to Know about Action Research. London, Sage.

Mellers, B.A.\& Schwartz, A., \& Ritov, 1. Emotion-based choice, Journal of Experimental Psychology:

General, 128 (1999), pp. 1-14

Newman, Tony (2004) What Works in Building Resilience? Ilford, Barnardos

Playwork Principles Scrutiny Group (200ㅌ) Playwork Principles (Online) Available from:

http://www.playwales.org.uk/eng/playworkprinciples

Robinson, Sir Ken, (2013), Finding Your Element, New York: Penguin 
Salovey, Peter, \& Mayer, John, (1990p189). Emotional intelligence. Imagination, cognition, and personality, 9(3), 185-211. 